\title{
Assessment of the Governance Performance of the Regulatory Regime Governing Foreign Mining Investment in the Philippines
}

\author{
Dr Vlado Vivoda ${ }^{1}$ \\ Research Fellow, Centre for International Risk, University of South Australia \\ Y3-46, Yungondi, City West Campus, UniSA, Adelaide, SA 5001, Australia \\ E-mail: vlado.vivoda@unisa.edu.au \\ Tel: +61 883027162
}

\begin{abstract}
This paper assesses the performance of the regulatory regime for foreign mining investment in the Philippines. Based on this, it outlines policy recommendations for the Philippine government, which, if implemented, are likely to improve the governance infrastructure in the sector, and in turn reduce regulatory risk for foreign mining investors and attract more foreign investment. The main argument is that the poor performance of the governance structures in the Philippine mining sector is behind the high level of regulatory risk for foreign mining investors, and the low levels of foreign investment. After outlining the relevant theoretical frameworks essential for the assessment of the performance of the regime, the article maps the regulatory regime governing foreign mining investment in the Philippines by summarising the major rules and regulations, institutions (rule-makers and regulators), and stakeholders in the Philippine mining industry. This is followed by the assessment of the performance of the regulatory regime for foreign mining investment. Finally, policy recommendations for improving governance infrastructure in the sector are outlined. This paper, unique in its subject area, may assist the Philippine government and possibly governments of other developing countries in improving governance infrastructure in their mining sectors, and thus reducing the level of regulatory risk and increasing the amount of foreign investment in the sector.
\end{abstract}

Keywords: $\quad$ The Philippines, Mining, Investment, Governance, Regulation

Word Count: $\quad$ 7,307 (excluding the abstract, footnotes, references, tables and figures)

\footnotetext{
${ }^{1}$ Dr Vlado Vivoda (vlado.vivoda@unisa.edu.au) is a Research Fellow at the Centre for International Risk, School of International Studies, University of South Australia, Adelaide, Australia. He would like to thank Dr Terry O’Callaghan for feedback on previous drafts.
} 


\section{Introduction: Regulatory Regimes, Governance Infrastructure and Foreign Direct Investment}

The term regulatory regime refers to "a historically specific configuration of policies and institutions which structures the relationship between social interests, the state and economic actors in an economy" (Eisner, 2000). Regulatory regimes consist of policies (formal procedures and informal processes/influences) and institutions (rule-makers and regulators) governing a particular industry sector. A regulatory regime, or environment, governing a particular industry is a part of the overall political, institutional and legal environment, or in other words, of governance infrastructure of a country. Governance infrastructure consists of "public institutions and policies created by governments as a framework for economic, legal and social relations" (Globerman and Shapiro, 2003). Governance infrastructure affects the investment decisions of MNCs. As a result, inflows of foreign direct investment (FDI) depend on the quality of a country's governance infrastructure (OECD, 2001; Globerman and Shapiro, 2002), and thus of regulatory regimes governing various industries in a given country.

The characteristics of regulatory regimes governing a particular industry are of pivotal concern to MNCs investing in developing countries. Logically, regulatory environments exhibiting certain characteristics which reduce risks for foreign investors are more likely to attract foreign investment than those with characteristics that increase risks. The central question then becomes - what characteristics/features of a regulatory regime reduce risk for MNCs / increase foreign investment inflows? Based on the survey of extant literature (see Brown and De Paula, 2002; Gutiérez, 2003; Cubbin and Stern, 2004; Kaufmann, Kraay and Mastruzzi, 2004; Kurtzman, Yago and Phumiwasana, 2004; Jamison, Holt and Berg, 2005; and World Resource Institute, 2005) six major regulatory risk variables inherent in regulatory regimes governing foreign investment in a particular industry are identified (See Table 1).

Table 1: Regulatory Regime Variables

\begin{tabular}{|l|l|}
\hline Regulatory regime variables & Description \\
\hline Clarity of rules and regulations & $\begin{array}{l}\text { If the rules and regulations are clear and not } \\
\text { contradictory, regulators will have an easier job } \\
\text { implementing them, which will reduce the possibility for } \\
\text { regulatory uncertainty and/or overlap, and thus reduce } \\
\text { the risk for foreign investors }\end{array}$ \\
\hline Policy and legal uncertainty & $\begin{array}{l}\text { If the overall government policy towards a particular } \\
\text { sector investment is stable and not challenged in the } \\
\text { courts, the rules and regulations governing that sector } \\
\text { are unlikely to be changed frequently; as a result, } \\
\text { guidelines issued to the regulators are unlikely to change } \\
\text { frequently, making implementation more stable, and } \\
\text { foreign investment less risky }\end{array}$ \\
\hline Regulatory capacity / efficiency & $\begin{array}{l}\text { If the regulators have sufficient capacity and are efficient } \\
\text { in their decision-making processes, the risk for foreign } \\
\text { investors is reduced }\end{array}$ \\
\hline $\begin{array}{l}\text { Regulatory transparency } \\
\text { accountability }\end{array}$ & $\begin{array}{l}\text { If the regulators are transparent and accountable in their } \\
\text { decision-making processes and dealings with the }\end{array}$ \\
\hline
\end{tabular}




\begin{tabular}{|l|l|}
\hline & $\begin{array}{l}\text { stakeholders, there is less likelihood of legal challenges } \\
\text { by the stakeholders, and thus less risk for foreign } \\
\text { investors }\end{array}$ \\
\hline Regulatory capture & $\begin{array}{l}\text { If the regulators are free of capture by any of the } \\
\text { stakeholders, there is less risk for foreign investors }\end{array}$ \\
\hline Regulatory overlap / conflict & $\begin{array}{l}\text { If the regulators are clear about their respective roles } \\
\text { there is less likelihood of regulatory overlap and/or } \\
\text { conflict; If there is no regulatory overlap and/or conflict } \\
\text { over 'ownership' of particular rules, there is less risk for } \\
\text { foreign investors }\end{array}$ \\
\hline
\end{tabular}

\section{Formal Procedures and Informal Influences}

Regulatory regimes are made up of both formal rules and procedures, and informal influences and processes, such as conventions and codes of behaviour (North, 1990). While regulatory regimes are designed to function according to formal procedures in practice they do not, and there is always a degree of informal influence on their operations. The best way to understand the difference between formal procedures and informal processes in the operations of regulatory regimes is to describe formal procedures as how they are supposed to function and informal processes as an incongruity between how hey are supposed to function and how they operate in practice. ${ }^{2}$ A range of rules and regulations outline the particularities about how a regulatory regime should function in practice, and generally specify the roles and responsibilities for all actors / agencies involved. Official channels for stakeholder participation in the regulatory process may be prescribed, and as such, do not constitute an informal process. An ideal regulatory process which functions by strictly adhering to formal procedures will be largely insulated from informal influences.

Issues arise, for instance, when formal specifications are broad, ambiguous, or contradictory, which allows for a degree of discretion on the part of decision-makers; when decision-makers have no capacity to act according to the formal rules and regulations; and when various decision-makers or the process as a whole is captured (see Table 2 ). If the degree of informality in a particular regulatory regime is high - for instance, if there is high degree of capture by sectional interests - this increases regulatory risks for foreign investors and reduces FDI inflows into the sector.

Table 2: Examples of Descriptors of Formal and Informal Regimes

\begin{tabular}{|l|c|c|}
\hline Clarity of rules and regulations ${ }^{3}$ & Formal Regime & Informal Regime \\
\hline Capacity of decision-makers to act & High & Low \\
\hline
\end{tabular}

\footnotetext{
${ }^{2}$ Incongruity rather than gap is a better word to describe the divergence between formal procedures and the actual performance of a regime. For instance a regulatory regime may: (a) not be acting in accordance to certain formal procedures (no B and D below); (b) be acting in accordance to other formal procedures (A, C, E, F below); and c) be acting in a way that is not prescribed by formal procedures ( $\mathrm{G}$ and $\mathrm{H}$ below).

How they are supposed to act: $\quad$ ABCDEF

This is how they act: A_C_EFGH

${ }^{3}$ Alternatively, procedural clarity.
} 
according to formal procedures

Independence of decision-makers from

informal sectional interests

Regulatory risk at industry level can be defined as risk arising from the quality of regulatory rules governing a particular industry, and from their application and enforcement (Moran, 1999). This paper assesses the performance of the Philippine regulatory regime governing foreign mining investment, against the six criteria outlined in Table 1. Given that investments in governance infrastructure and in improving the regulatory environment in particular are likely to reduce regulatory risks for foreign investors and as a result are likely to attract foreign capital, this paper proposes the ways in which the Philippine government can improve the performance of its regulatory regime governing foreign mining investment. This paper adds to the relevant literature in several ways. Most prominently, it is unique in its subject area, as there have been no similar assessments of the performance of governance structures in the Philippine mining sector. Moreover, it proposes the ways in which governance infrastructure in the mining sector in the Philippines can be improved in order to reduce regulatory risk for foreign investors and attract more foreign investment into the sector. It is likely that the lessons learnt in the Philippines may be useful in improving governance in other developing countries' mining sectors.

The paper proceeds as follows. In Section 2, in order to gain a thorough understanding of the Philippine regulatory regime governing foreign mining investment, the formal rules and regulations which form the foundation of the regime, are outlined. This is followed by analysis of the institutions (rulemakers and regulators) and stakeholders involved. In Section 3, the performance of the Philippine regulatory regime governing foreign mining investment is assessed against the criteria set in Table 1. Finally, in Section 4 , policy recommendations on how to improve the performance of the Philippine regulatory regime governing mining investment are outlined.

\section{Mapping the Formal Regulatory Regime Governing Foreign Mining Investment in the Philippines}

Although there may be a degree of overlap, the regulatory regime that governs the mining industry in the Philippines, or any other country, differs from that governing other industries. For example, certain rules and regulations that are relevant for foreign mining investors interested in establishing mining operations significantly differ from rules and regulations relevant for foreign health or tourism industry investors. While the overlap is commonly evident in the overall foreign investment regulations, specific sector-based regulation is likely to be significantly different. Similarly, although there is a degree of overlap among the institutions involved in various issue areas, in particular among the rulemakers, the regulators are likely to be exclusively different. 
The mining potential of the Philippines is substantial, as the country holds reserves of precious metals (gold, silver, platinum); base metals (copper, lead, zinc, mercury, cadmium); iron alloys (chromite and nickel); light metals (bauxite and manganese); and iron (Mines and Geosciences Bureau). Based on density of deposits per square kilometre of land area, the country is ranked third in the world in gold deposits, fourth in copper reserves, fifth in nickel, and sixth in chromite (Business World, 2005). Although there has been a long history of mining in the Philippines, the negative investment climate throughout much of the 1980 s resulted in the under-use of the mining industry in promoting socioeconomic development (Otto, 1992). However, since the 1990s the Philippine government has encouraged mining and strived to attract foreign investment. For instance, the Philippines are one of the developing countries which have, in recent years, made a significant effort to attract foreign investment into their mining sectors (Bridge, 2004). In March 1995, President Fidel Ramos signed into law the Mining Act, the statute which has been sought by the Philippine mining industry through the Philippine Chamber of Mines since ratification of the Philippine Constitution in 1987 (Otto, 1992).

There are various documents which form the foundation of the formal regulatory regime governing foreign mining investment in the Philippines (see Table 3), and there is a certain degree of overlap between various regulations.

Table 3: Regulations Governing Foreign Mining Investment in the Philippines

\begin{tabular}{|l|l|}
\hline Name of Regulation & Relevance for Mining Investors \\
(Section 2, Article XII) & $\begin{array}{l}\text { Spells out the guiding principles for mining in the } \\
\text { Philippines; although the State owns all mineral } \\
\text { resources, it may enter into agreements with private } \\
\text { contractors for the exploitation of mineral resources }\end{array}$ \\
\hline $\begin{array}{l}\text { Mining Act of } 1995 \text { (Republic Act } \\
\text { No. 7942) }\end{array}$ & $\begin{array}{l}\text { The regulation governing mining; created in order to } \\
\text { revive the Philippine mining industry; defines the } \\
\text { agreements for mineral exploitation and also provides } \\
\text { the requirements for acquiring mining rights; governs } \\
\text { the exploration, development, processing and } \\
\text { utilisation of mineral resources in the Philippines; } \\
\text { through Financial or Technical Assistance Agreements } \\
\text { (FTAAs), it allows for 100 percent foreign ownership of } \\
\text { the mining project; it also contains several incentives to } \\
\text { encourage mining, such as a four-year income tax } \\
\text { holiday, tax and duty-free capital equipment imports, } \\
\text { value-added tax exemptions, income tax deductions } \\
\text { where operations are posting losses, and accelerated } \\
\text { depreciation }\end{array}$ \\
$\begin{array}{l}\text { The Foreign Investment Act (FIA) } \\
\text { of 1991 (R.A. No. 7042) amended } \\
\text { by R.A. No. 8179 }\end{array}$ & $\begin{array}{l}\text { The general foreign investment regulation, and as such, } \\
\text { it governs the entry of foreign investment and doing of } \\
\text { business by foreigners without incentives; it also sets } \\
\text { into place the procedures for the registration and grant } \\
\text { of incentives to foreign investors, and specifies the } \\
\text { limits on the extent of allowable foreign ownership }\end{array}$ \\
\hline $\begin{array}{l}\text { The Omnibus Investment Code of } \\
\text { 1987 (Executive Order No. 226) } \\
\text { amended by R.A. No. 8756 }\end{array}$ & $\begin{array}{l}\text { Provides the rules by which foreign investment in the } \\
\text { Philippines may qualify for certain incentives }\end{array}$ \\
\hline
\end{tabular}




\begin{tabular}{|c|c|}
\hline $\begin{array}{l}\text { The Special Economic Zone Act of } \\
1995 \text { (R.A. No. 7916), and the } \\
\text { Export Development Act of } 1994 \\
\text { (R.A. No. 7844) }\end{array}$ & $\begin{array}{l}\text { Outline further conditions under which fiscal incentives } \\
\text { apply }\end{array}$ \\
\hline $\begin{array}{l}\text { The Foreign Investment List (E.O. } \\
\text { No. 286) }\end{array}$ & $\begin{array}{l}\text { Defines the areas where restrictions on foreign } \\
\text { ownership as specified by the Constitution and certain } \\
\text { laws exist }\end{array}$ \\
\hline $\begin{array}{l}\text { The National Internal Revenue } \\
\text { Code of the Philippines, or "the } \\
\text { Tax Code" (Presidential Decree } \\
\text { No. 1158), amended in } 1997 \text { by } \\
\text { R.A. No. } 8424 \text { (The Tax Reform } \\
\text { Act) }\end{array}$ & Provides the general framework for the tax regime \\
\hline $\begin{array}{l}\text { The } 1991 \text { Local Government Code } \\
\text { (LGC) of the Philippines, or "the } \\
\text { decentralization code" (R.A. No. } \\
7160 \text { ) }\end{array}$ & $\begin{array}{l}\text { Specifies the consensual local government requirement } \\
\text { for any mining project to proceed, and the share of } \\
\text { mining taxes going to the local government; it also } \\
\text { entrusts the local government units (LGUs) with } \\
\text { overseeing environmental management (Courtney et al., } \\
\text { 2002) }\end{array}$ \\
\hline $\begin{array}{l}\text { The } 1980 \text { Corporation Code of the } \\
\text { Philippines (Batas Pambasa Bilang } \\
68 \text { ) }\end{array}$ & $\begin{array}{l}\text { Provides for the rules and regulations in the } \\
\text { establishment and operation of stock and non-stock } \\
\text { corporations in the Philippines }\end{array}$ \\
\hline $\begin{array}{l}\text { The } 2000 \text { Securities Regulation } \\
\text { Code (R.A. No. 8799) }\end{array}$ & $\begin{array}{l}\text { Governs the regulation of securities and practices in } \\
\text { the stock market }\end{array}$ \\
\hline $\begin{array}{l}\text { The Indigenous Peoples' Rights } \\
\text { Act (IPRA) of } 1997 \text { (R.A. No. 8371) }\end{array}$ & $\begin{array}{l}\text { Contains important provisions concerning mining } \\
\text { activities in ancestral domain and ancestral lands, and } \\
\text { warrants that no mineral agreement shall be approved } \\
\text { unless there is 'free, informed and prior consent' (FIPC) } \\
\text { from indigenous peoples; }\end{array}$ \\
\hline $\begin{array}{l}\text { DENR Administrative Order No. } \\
96-40\end{array}$ & $\begin{array}{l}\text { Requires mining companies to undertake an } \\
\text { Environmental Protection and Enhancement Programme } \\
\text { after they were granted an Environmental Compliance } \\
\text { Certificate (ECC) }\end{array}$ \\
\hline $\begin{array}{l}\text { The Ecological Solid Waste } \\
\text { Management Act of } 2000 \text { (R.A. } \\
\text { No. 9003), the Toxic Substances } \\
\text { and Hazardous and Nuclear } \\
\text { Wastes Control Act of } 1990 \text { (R.A. } \\
\text { No. 6969), the Clean Air Act of } \\
1999 \text { (R.A. No. 8749), and the } \\
\text { Wildlife Resources Conservation } \\
\text { and Protection Act of } 2001 \text { (R.A. } \\
\text { No. 9147) }\end{array}$ & Contain other relevant environmental legislation \\
\hline $\begin{array}{l}\text { The Investor's Lease Act of } 1993 \\
\text { (R.A. No. 7652) }\end{array}$ & Sets the rules for land leasing \\
\hline $\begin{array}{l}\text { The Labor Code of the Philippines } \\
\text { of } 1974 \text { (P.D. No. } 442 \text { ) }\end{array}$ & Contains labour standards and relations legislation \\
\hline $\begin{array}{l}\text { The Small-scale Mining Act of } \\
1991 \text { (R.A. No. 7076) }\end{array}$ & $\begin{array}{l}\text { Governs small-scale mining, which may in } \\
\text { foreigners }\end{array}$ \\
\hline
\end{tabular}

It is evident from Table 3 that there is a wide array of rules and regulations that govern the regulatory regime for foreign mining investment in the Philippines. These rules are created by numerous rule-makers and enforced by the regulators. While the rule-makers can be defined as individuals, groups, or institutions directly in charge of crafting rules and regulations, the regulators are individuals, groups, or institutions that ensure compliance with laws, regulations, and established rules. 
With regards to foreign mining investment regulation in the Philippines, the main rule-makers are the House of Representatives of the Philippines and Senate of the Philippines, the President, the Supreme Court, the Department of Energy and Natural Resources (DENR), which issues implementing rules and regulations, the National Economic and Development Agency (NEDA), which is responsible for formulating social and economic policies, and various local government units (LGUs), at provincial, municipal and barangay levels. Various house and senate committees, in particular House Committee on Natural Resources and Senate Committee on Environment and Natural Resources, possess congressional agenda-setting power over matters which involve mining. However, numerous other committees have overlapping jurisdiction.

The existence of a complex web of regulators governing compliance with and enforcement of rules and regulations (see Table 3) does not come as a surprise given the number and complexity of formal rules and regulations. Their roles are summarised in Table 4.

Table 4: Roles of the Major Regulators in the Philippine Mining Sector

\begin{tabular}{|c|c|}
\hline Regulator & Role \\
\hline $\begin{array}{l}\text { The Department of Energy and } \\
\text { Natural Resources (DENR) and } \\
\text { its Mines and Geosciences } \\
\text { Bureau (MGB) and } \\
\text { Environmental Management } \\
\text { Bureau (EMB) }\end{array}$ & $\begin{array}{l}\text { Administers the implementation of the } 1995 \text { Mining Act } \\
\text { (through MGB); oversees environmental management, } \\
\text { conservation and development (through EMB); oversees } \\
\text { the issuance of Environmental Compliance Certificate } \\
\text { (ECC) based on the Environmental Impact Statement (EIS), } \\
\text { which sets out the likely environmental consequences of } \\
\text { the mining project and the mitigation measure that can } \\
\text { be implemented to lessen, or eliminate, these } \\
\text { environmental effects (through EMB) }\end{array}$ \\
\hline $\begin{array}{l}\text { The Department of Agriculture } \\
\text { (DOA) and its Bureau of } \\
\text { Fisheries and Aquatic Services } \\
\text { (BFAS) }\end{array}$ & $\begin{array}{l}\text { Administers the management, conservation, } \\
\text { development, protection, utilisation and disposition of all } \\
\text { fishery and aquatic resources of the country (except for } \\
\text { municipal waters, which are under the control of the } \\
\text { municipal or city governments) }\end{array}$ \\
\hline $\begin{array}{l}\text { The National Commission on } \\
\text { Indigenous Peoples (NCIP) }\end{array}$ & $\begin{array}{l}\text { Through indigenous cultural communities and } \\
\text { indigenous peoples' authorised representatives, } \\
\text { administers the issuance of the Certificate of Free and } \\
\text { Prior Informed Consent (FCIP), which is required before } \\
\text { any mining project may be introduced in any area } \\
\text { covered by the ancestral domain; it is also responsible for } \\
\text { ensuring adherence to the implementing rules and } \\
\text { regulations of the IPRA }\end{array}$ \\
\hline $\begin{array}{l}\text { The Department of Finance } \\
\text { (DOF) and its Bureau of Internal } \\
\text { Revenue (BIR) and Bureau of } \\
\text { Customs (BOC) }\end{array}$ & Assesses and collects revenues \\
\hline $\begin{array}{l}\text { The Department of Interior and } \\
\text { Local Government (DILG) }\end{array}$ & ions \\
\hline Local Government Units (LGUs) & $\begin{array}{l}\text { Their approval is required for potential mining } \\
\text { operations to proceed; assess and collect revenues at } \\
\text { locations where there is mining activity }\end{array}$ \\
\hline $\begin{array}{l}\text { The Office of the President and } \\
\text { its Housing and Land Use }\end{array}$ & 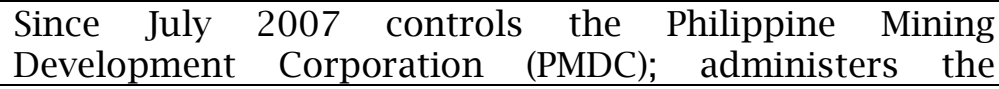 \\
\hline
\end{tabular}




\begin{tabular}{|l|l|}
\hline Regulatory Board (HLURB) & $\begin{array}{l}\text { disposition of all cancelled mining permits; approves the } \\
\text { transfer or assignment of financial or technical assistance } \\
\text { agreements (FTAA); and regulates the land use (through } \\
\text { HLURB). }\end{array}$ \\
\hline $\begin{array}{l}\text { The Securities and Exchange } \\
\text { Commission (SEC) }\end{array}$ & $\begin{array}{l}\text { Grants and revokes licences for foreign mining investors } \\
\text { operating under the FIA of 1991 and the Omnibus } \\
\text { Investment Code; responsible for ensuring the } \\
\text { compliance of all market participants with regulations } \\
\text { and legislation; foreign investors are required to register } \\
\text { with SEC if not single proprietorships }\end{array}$ \\
\hline $\begin{array}{l}\text { The Department of Trade and } \\
\text { Industry (DTI) and its Bureau of } \\
\text { Prade Regulation and Consumer } \\
\text { Board of Investment and the }\end{array}$ & $\begin{array}{l}\text { Foreign investors are required to register with the BTRCP } \\
\text { in the case of single proprietorship; the BOI evaluates and } \\
\text { supervises investment applications, and if a company is } \\
\text { listed in the Investment Priority Plan (IPP), the BOI entitles } \\
\text { it for incentives }\end{array}$ \\
\hline $\begin{array}{l}\text { The Bangko Sentral ng Pilipinas } \\
\text { (BSP) }\end{array}$ & Oversees registration of foreign investment \\
\hline $\begin{array}{l}\text { The Philippine Stock Exchange } \\
\text { (PSE) }\end{array}$ & $\begin{array}{l}\text { Regulates operations of listed mining companies so that } \\
\text { they operate under the rules of the exchange }\end{array}$ \\
\hline
\end{tabular}

The regulators are engaged in ensuring compliance with laws, regulations, and established rules by various stakeholders. According to Freeman, Harrison and Wicks (2007), a stakeholder is "any group or individual who can affect or is affected by the achievement of a corporation's purpose". Freeman et al (2007) examine stakeholders from a firm-centric perspective. However, given that this paper considers stakeholders from a regime-centric perspective, a more appropriate definition of a stakeholder is any group or individual who is affected by the functioning of a sector-specific regulatory regime. In the case of regulatory regime governing mining investment in the Philippines, there are numerous stakeholders, and generally, they can be divided into pro-mining and anti-mining groups (see Figure 1).

Figure 1: Key Stakeholder Map 


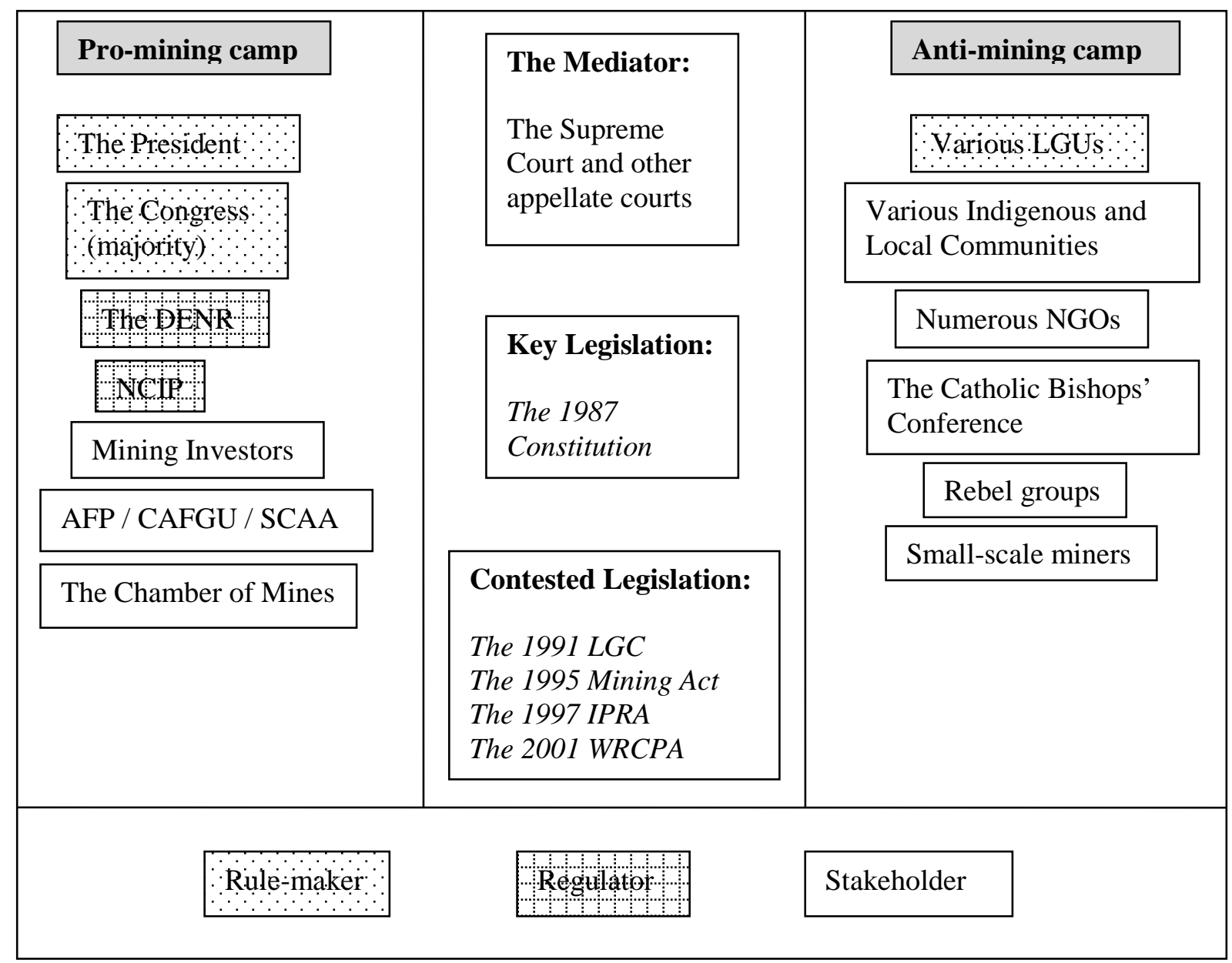

Note: The DENR can also act as a rule-maker, and LGUs can act as regulators.

Among pro-mining stakeholders, the most obvious group are the mining companies, both foreign and domestic, and the Chamber of Mines, which serves as a lobby group for the mining industry. There are many foreign mining companies, mainly from Australia, Canada, and Japan, but also from the UK, South Korea, Switzerland, China, South Africa, and the US, which through its subsidiaries operate in the Philippines. There are also various domestic mining companies, which engage in mining operations either on their own or in partnership with subsidiaries of foreign companies.

Since they are interested in increasing government income generated from mining, it is unsurprising that the President and various other governmental departments are also in the pro-mining camp. This includes the NCIP, which has repeatedly been accused of favouring the mining companies over the indigenous peoples on the issue of ancestral lands and domains (FactFinding Mission, 2006). The mainstream media largely privileges company positions over those of local communities. However, various non-mainstream internet news websites, such as Mindanews, tend to be anti-mining. The Armed Forces of the Philippines (AFP) are committed to providing peaceful and stable environments for investments, particularly providing the foreign investors safety from rebel and terrorist threats, and this implies that they are pro-mining. The Special Civilian Armed Auxiliary (SCAA), which is trained and equipped by the AFP, but paid by mining companies (Girouard, 1996) 
has much to gain from mining, and SCAA guards are often used by mining firms to ensure safety on and around the mining sites. The AFP and the SCAA have faced allegations that they behave in a heavy-handed manner when deployed to protect mining projects, as in 2004 at the Canatuan mining site (Rodell, 2004, Linantud, 2005, Fact-Finding Mission, 2006).

Large-scale mining had created divisions among local and indigenous communities, and while some favour it as they see it as the only way out of poverty, others are opposed. Many indigenous communities that are opposed to foreign mining feel that mining companies lack respect for their traditional cultures (Fact-Finding Mission, 2006). Local communities are commonly allied with NGOs and the Catholic Church in their active resistance to mining. This constituency is represented by indigenous peoples' organisations, environmental and legal NGOs working with local communities, local political leaders, and the Catholic Church (Stark, 2007). In addition, small-scale miners are also often opposed to large-scale mining development and rehabilitation of existing mines (Chase and Lugue, 2006), and some have suggested that the opening up of mining in the Philippines to foreign corporations "has resulted in increasing confrontations between these companies and small-scale miners" (Fact-Finding Mission, 2006).

The Catholic Church, represented through The Catholic Bishops' Conference of the Philippines (СВCP) is staunchly anti-mining, officially arguing that "dislocation of communities, the risks to health and livelihood, massive environmental damage, and the loss of mining resources to foreign companies, far outweigh economic benefits of mining" (CBCP, 2006). The Church influences every level of administration in the Philippines, so much so that only after pressure from the Church, Manila announced that it would review the 1995 Mining Act (Chase and Lugue, 2006). Many in the Church argue that corruption in the Philippines is too extensive to allow an activity with as many potential deleterious effects as mining to be beneficial for the country (Estabillo, 2005, Holden and Jacobson, 2007a). In the anti-mining camp, many indigenous communities and the Catholic Church are allied with a wide variety of non-governmental organisations (NGOs), the most vocal of which is Kalikasan People's Network for the Environment (Kalikasan PNE). It may be worth mentioning in this context that the Philippines are known to have one of the most dynamic nongovernmental organisation communities in the world (Aldaba, 2002, Bryant, 2005).

Mining incidents, such as the Marcopper (1993 and 1996) and Rapu Rapu (2005) disasters, and the lingering issues surrounding abandoned mines have led to a growing constituency against large-scale mining in the Philippines in the past two decades. Some communities have alleged that mining companies and their employees repeatedly violate environmental standards and human rights (Christian Aid, 2004). For example, anti-mining groups and tribespeople have accused the mining companies of failing to widely consult them and get their consent (Konstantin Galvez, 2007). There are reports of arbitrary detentions, persecutions and even killings of community representatives, mass evacuations, hostage taking, destruction of 
property, summary executions, forced disappearances, coercion, and rape by armed forces, the police or paramilitaries (Gaerlan, 2005). The Catholic Church alleges that "increasing number of mining affected communities, Christians and non-Christians alike, are subjected to human rights violations and economic deprivations" (CBCP, 2006).

Insurgent and rebel groups, such as the Communist National People's Army (NPA), Abu Sayyaf, and the Moro Islamic Liberation Front (MILF) are another active stakeholder group in mining operations in the Philippines, which are opposed to mining by foreign corporations (Holden and Jacobson, 2007b). Many of the mineral-rich lands of the Philippines lie in, or close to, areas where these Communist insurgents and Muslim rebels are active. For instance, the NPA has a long history of extorting money from mining companies, which it refers to as 'revolutionary taxation' (Le Billon, 2005). A mining company that fails to pay revolutionary taxes may find its facilities attacked, equipment destroyed, and personnel killed. Similarly, there are instances of the MILF extorting money from businesses in Mindanao (Holden and Jacobson, 2007b). For example, it has been alleged that Canada's Echo Bay Mines paid over US\$1.7 million in three years to various armed groups including the NPA, the MILF and also Abu Sayyaf (Snell, 2004). Since there have been many instances of armed groups attacking mining companies it is clear that the security threat for mining investors is real.

\section{Summary}

Above, in order to gain a thorough understanding of the Philippine regulatory regime governing foreign mining investment, the formal rules and regulations which form the foundation of the regime, were outlined. This was followed by analysis of the institutions (rule-makers and regulators) and stakeholders involved. It is clear that the regime is highly complex - there are numerous rules and regulations (20 relevant statutes) and regulators (11 agencies and 8 sub-agencies) that govern the industry investment. In addition, there is a wide array of stakeholders, roughly divided into promining and anti-mining camps. Given the complexity of the regime, it would not come as a surprise if foreign investors find navigating the regime to be risky, complicated and burdensome. However, this section was not meant to assess the quality of the regime, but simply to outline its features and characteristics, as a basis for critical assessment in the following section.

\section{Assessing the Quality of the Regulatory Regime Governing Foreign Mining Investment in the Philippines}

Although the government has been committed to attracting foreign mining investment and it enacted attractive mining legislation, it has only had limited success in attracting foreign mining investment. Between 2004 and 2007 , the country attracted $\$ 1.4$ billion in mining investment, falling short of the $\$ 2.4$ billion target. Amid expectations that global mining giants, such as Xstrata, will invest in the country, the government hopes to attract as much as $\$ 4.1$ billion in 2010 (Landingin, 2008). The Philippines' mineral potential 
makes it one of the world's five most attractive mining investment destinations. However, despite enormous mineral potential, the mining industry's economic impact remains negligible - jobs created are only 0.4 percent of total employment, and revenue is less than 1 percent of total government collection each year (Go, 2008). The reasons for the lack of success in attracting foreign mining investment stem from the nonperforming regulatory regime which generates risk for foreign investors and thus inhibits foreign investment. Below, the performance of the Philippine regulatory regime governing foreign mining investment is assessed against the six main criteria which determine the quality of a regulatory regime.

\section{i. Clarity of Rules and Regulations}

There are twenty statutes and regulations that govern various aspects of foreign mining investment in the Philippines (see Table 3). Given the high number of relevant regulations, it is not surprising that the rules and regulations are unclear and contradictory. Of particular concern are the Mining Act of 1995, the Wildlife Resources Conservation and Protection Act (WRCPA) of 2001, the Local Government Code (LGC) of 1991, the Indigenous Peoples' Rights Act (IPRA) of 1997, and the Tax Reform Act (TRA) of 1997. For instance, the 1995 Mining Act, which governs the exploration, development, processing and utilisation of mineral resources, gives overlapping rule 'ownership' to the central government (the DENR) and to the LGUs. The Mining Act also contradicts the LGC, the WRCPA, and the IPRA, with regards to provisions about mining, indigenous and environmental approval processes, respectively. In addition, the LGC gives overlapping rule 'ownership' to the DILG and the LGUs, and the TRA gives overlapping rule 'ownership' to the BIR and the LGUs with regards to taxation. As a result, legal challenges and uncertainty, and regulatory overlap/conflict are frequent. This, in turn, increases the risk for foreign investors, and reduces the influx of mining FDI.

\section{ii. $\quad$ Policy and Legal Uncertainty}

Policy reversals and inconsistencies have been one of the key reasons the Philippines have been unable to earn sufficient trust from the international mining industry. In The Fraser Institute Annual Survey of Mining Companies 2006/07, 43 percent of the respondents stated that they viewed uncertainty concerning the administration, interpretation and enforcement of existing regulations as a strong deterrent to investment (Fraser Institute, 2007).

Philippine civil society groups have repeatedly acted in the courts against mining, and perhaps the best examples are its challenge to the 1995 Mining Act and defence of the IPRA. In 1998, triggered by the Marcopper tailings spill communities, NGOs and the Catholic Church rallied for the repeal of the 1995 Mining Act and replacement by a more socially and environmentally precautionary law (Christian Aid, 2004). After a prolonged legal battle, in January 2004 the Supreme Court struck down as unconstitutional parts of the Mining Act permitting full ownership of mining 
operations through the FTAA. The ruling, which affected US\$350 million of investments, has been overturned in December 2004, and the reversal of a challenge to the 1995 Mining Act by the Supreme Court marked the beginning of recent efforts to resuscitate the industry. However, the October 2005 Rapu-Rapu incident was followed by a renewed backlash from the antimining constituency and pressure on President Arroyo to review the mining law. As a result, in March 2006, Arroyo ordered a review of the Mining Act, which confirmed policy uncertainty (Landingin, 2008). Overall, in the 13 years of the existence of the Mining Act, seven were spent mired in defending its constitutionality by the Supreme Court. Currently, there are several Senate bills and resolutions seeking to appeal or amend the law and review its constitutionality.

The December 2004 decision by the Supreme Court to overturn the January 2004 ruling that the 1995 Mining Act was constitutional contains a number of stringent decisions, which may cause significant uncertainty for mining investors with FTAAs in the Philippines. Firstly, regardless of the 100 percent foreign-ownership provision, minerals will always remain subject to the full control and supervision of the state. Secondly, the state retains power to direct overall strategy and to set aside, reverse or modify plans and actions of the contractor. Thirdly, while the President is given the prerogative to determine the net mining revenues between the contractor and the state, if there is deemed to be grave abuse of discretion in the execution of this prerogative the Supreme Court may nullify specific provisions of the FTAA that are contrary to law or are manifestly and grossly disadvantageous to the nation. Finally, the court cautioned the President to take appropriate steps to secure the best terms and conditions given the circumstances, and made the officials responsible for entering into disadvantageous agreement viable to answer to the court for their malfeasance (Philippine Supreme Court, 2004). Thus, overall, it becomes obvious that contracts are not very secure and that changes in administration, or challenges to the real benefits of specific FTAAs in the courts, may result in their being declared void (Fact-Finding Mission, 2006).

The Philippines Congress' passing of IPRA in late 1997, and the legal ramification that followed, serve as yet another case in point regarding policy and legal uncertainty in the Philippines. In The Fraser Institute Annual Survey of Mining Companies 2006/07, 45 percent of the respondents stated that they viewed uncertainty over indigenous rights to be a deterrent to investment in the Philippines (Fraser Institute, 2007). When IPRA was passed in 1997, it was "considered a blow to the mining industry" (Starke, 2002), and together with the LGC, IPRA includes provisions that, if upheld, would strengthen the protection of communities in the path of mining development.

IPRA provides for a wide range of indigenous peoples' rights, such as the right to ancestral domain, the right to self-governance, and the right to cultural integrity (Stavenhagen, 2003). In 1998, IPRA also created the NCIP and issued the Implementing Rules and Regulations (IRRs) for IPRA, which 
among other provisions, required the FPIC of indigenous communities as a precondition to mining operations, and this novel regulation was considered high risk by mining investors, since half of all the areas identified in mining applications were in areas subject to the provisions of IPRA and its IRRs (Holden, 2005). The mining industry requires access to significant tracts of land for exploration. Denial of access from an indigenous community creates a serious impediment to mineral development (Holden and Ingelson, 2007b). As a result, between 1998 and 2001, the mining industry challenged IPRA's constitutionality, on the basis that it violated the 1987 Constitution by virtue of the fact that Section 2 of Article XII gives the Philippine State the property rights of all natural resources. While the mining industry did not succeed in its attempt to invalidate IPRA, as it was declared constitutional in September 2001, its efforts did have some success in convincing the NCIP to weaken the FPIC provisions of the implementing rules and regulations (Holden and Ingelson, 2007).

Legal uncertainty is also caused by the much delayed release of streamlined and harmonised guidelines and administrative orders for the processing of FPIC certification that is to be facilitated by the NCIP, and by the apparent ability to challenge at will almost any aspect of the law. For example, there is a looming threat in Senate Bill No. 2411 entitled 'Rationalisation and Harmonisation of Fiscal Incentives'. This bill is perceived to seek to "rationalise" (interpreted by industry as to change, remove or reduce) investment incentives across industries. The removal of such incentives would reduce viability and attractiveness of mining investments in the country (Chase and Lugue, 2006).

\section{iii. Regulatory Capacity / Efficiency}

A weak Philippine state has produced weak and inefficient institutions of governance (Milo, 2007), which lack regulatory capacity. For instance, although both the Mining Act and the IPRA highlight the importance of FPIC to mining affected communities, evidence suggests that the agencies in charge of these areas, in particular the MGB and the NCIP have failed to effectively apply the law due to severely limited resources to enforce legal provisions. Their resources are limited both in terms of budget and the considerable expertise required to deal with complex matters of consent in indigenous communities. For instance, local governments do not have the capability to estimate the projected benefits of mining, and even the DENR "has few experts on natural resources valuation" as most left the agency to become consultants in the private sector (Landingin, 2008). The large number of applications from mining companies makes their task even more difficult (Christian Aid, 2004). Given the fact that the government lacks the resources to enforce rules across the mining sector, it is unsurprising that bureaucratic inefficiencies are pronounced (Bhargava and Bolongaita, 2004) and that enforcement of regulations is slow, erratic and inefficient (EIU, 2007). Red tape in the approval of permits by both local and national governments is slowing the rehabilitation of existing mines and the development of new ones (Chase and Lugue, 2006). Institutional incapacity, 
delay and inefficiency in the delivery of public services by the government are very common, and this weakens the effective functioning of the regulatory regime governing foreign mining investment in the Philippines.

\section{iv. Regulatory Transparency / Accountability}

Access to adequate mining information is very difficult in the Philippines. In a recent study, the DENR, and the MGB and the EMB in particular, have been found to be "averse to disclosing information to the public", and it was argued that looking for mining-related data issued to mining companies is "as difficult as digging up the precious metals themselves" (Aguilar, 2008). The Philippine environmental impact assessment (EIA) process, administered by the DENR, views all environmental impacts statements submitted by mining companies to the government as confidential. For example, when communities in the Zamboanga Peninsula, on the island of Mindanao, asked for the release of public documents related to potential mining operations in the area, MGB Director told them that the requested documents could not be released without the consent of the mining firms (Holden and Jacobson, 2006).

The lack of transparency goes a long way towards explaining why some communities have withheld consent and why others have gone so far as to implement mining moratoriums. If members of the community are denied information about the risks of the project they are asked to consent to, they are being asked to make a decision that involves a degree of uncertainty. If this is coupled with the knowledge about mining disasters at Marcopper and Rapu-Rapu, local government and community opposition to mining is understandable. The lack of transparency on the part of the major regulating agency in the Philippine mining sector is matched by the lack of accountability to the public. Provisions for public participation in EIAs are eroded in the name of 'streamlining' application processes. Recent DENR Administrative Orders have weakened participation rights, including the right to information, participation in decision-making and access to legal help (Fact-Finding Mission, 2006).

\section{v. Regulatory Capture}

A weak Philippine state has produced inefficient institutions of governance which lack independence. The basic institutions and governance structures in the Philippines are dominated by powerful vested interests, who through informal influences, such as patronage politics, corruption, cronyism and clientelism, control the Philippine state. For instance, large family conglomerates, or clans, dominate the economy (Milo, 2007). There are an estimated 250 political families nationwide, with at least one in every province, occupying positions in all levels of the bureaucracy, and of the 265 members of Congress, 160 belong to clans (Conde, 2007). Businesses owned and operated by these families and friends of high officials often receive preferential treatment and regulations are often not fairly applied to those in positions of influence. The Philippine state is weak as a result of relative 
autonomy from the vested interests of dominant Filipino social classes, powerful political families and clans, an influential landed elite, and wealthy Filipino capitalists (Hutchcroft, 1997, Banlaoi, 2004).

To illustrate, many NGOs have been suspicious of the rationale behind the fact that two Arroyos (Gloria and Ignacio) currently control both the Philippine Mining Development Corporation (PMDC) and the House Committee on Natural Resources and Environment. Arguably, there is a blatant conflict of interest with President Arroyo's assumption of control over the PDMC in 2007, which oversees mining development and the approval of new mining projects, and House Representative Arroyo's chairing of the House Committee which is tasked to investigate problems related to environment and natural resources, many of which are related to previous, current and future mining projects in the country. According to Clemente Bautista of Kalikasan PNE, this lethal combination implies that "Pres. Arroyo can just approve mining contracts left and right with the PDMC under her control, while Rep. Arroyo can very easily block calls for Congressional probes into mining-related environmental disasters or mining deals that may be anomalous, dangerous, and plunderous by virtue of his position" (Bautista, 2007).

Besides cronyism, corruption and graft are so pervasive that they can be regarded as impediments to the implementation of an effective and accountable regulatory framework responsible for overseeing mining investment in the Philippines. For instance, the Department of Environment and Natural Resources (DENR) is, according to one report, one of the most graft-ridden and corrupt institutions in the Philippines (SAPRIN, 2001). Moreover, corruption becomes an acutely salient issue whenever consent is required as a precondition of mining, be it from indigenous people through the auspices of IPRA, or from LGUs, within the aegis of the LGC (Holden, 2005). There is also evidence of mining companies paying money to insurgent groups as a way of forestalling violent attacks upon their facilities (Holden and Jacobson, 2007b). Cronyism, corruption and graft prevalent in the Philippine mining regulatory regime, which allow for regulatory capture by sectional interests, result in low public support and trust in the regime, and are some of the main obstacles to increased foreign mining investment in the Philippines.

\section{vi. Regulatory Overlap / Conflict}

Given the complexity of the rules and regulations and the number of regulators involved in administration of the mining-sector foreign investment in the Philippines, there is significant overlap and conflict of jurisdiction among various agencies and levels of government. In general, conflicts of jurisdiction occur at the central level between the DENR, the singular government body responsible for mining, and other national agencies such as the Department of Agriculture, and at the provincial levels, between the DENR and LGUs. Generally, each agency tends to focus on the sector that it is supposed to regulate, almost neglecting the impact of its 
actions on the other sectors "outside" its purview (Cariño, 2002). Moreover, the system of checks and balances among government branches often results in inter-branch conflict and policy gridlock, as evident from the Supreme Court's support for LGUs and thus opposition to central government. This is particularly so if judges shift from strict legal interpretation into policymaking, which is often the case (EIU, 2007). It is thus unsurprising that 42 percent of the respondents in The Fraser Institute Annual Survey of Mining Companies 2006/07 viewed regulatory duplication and inconsistencies as a strong deterrent to investment in the Philippines (Fraser Institute, 2007).

The Philippine civil society has been most effective in opposing the activities of the mining industry in the realm of the LGUs, through which they caused regulatory conflict with the national government. Traditionally, government in the Philippines has been highly centralised. However, in 1991 some powers and functions that used to be performed by the national government were transferred to LGUs (Balgos, 2001, Legaspi, 2001). For instance, the Local Government Code (LGC) of 1991 requires that local governments be consulted with regard to development initiatives, including mining operations, within their jurisdiction. In practice, however, this requirement is at times over-ridden by national government (Fact-Finding Mission, 2006), and in 1999 the DENR attempted to minimize the ability of local governments to withhold consent by issuing an administrative order stating that only two of the three local governments need consent to a mining project (Holden and Jacobson, 2006). The DENR's attempted overriding of LGU power did not materialise as the LGC requires the consent of all affected local governments (Ballesteros, 2001), and as this administrative order was passed by the DENR, a government agency, it cannot pre-empt the provisions of the LGC, a statute passed by the Philippine Congress. As a result, four provinces (Capiz, Aurora, Mindoro Oriental, and Eastern Samar) in the country have so far passed resolutions banning mining in their areas (Chase and Lugue, 2006). Subsequently, the DILG issued an opinion stating that LGU moratoriums are invalid (Holden and Jacobson, 2006). Nevertheless, moratoriums on mining show that local governments have substantial power over decisions regarding mining investment in their jurisdictions, and the reluctance of certain local governments to consent to mining projects is evidence that some LGUs have come into conflict with the mining-based development paradigm pursued by the national government. The Supreme Court and other courts in the Philippines have encouraged and supported LGUs to uphold environmental protection legislation (Holden and Jacobson, 2006).

On one hand, in declaring that LGU mining moratoriums were invalid, the DILG based its opinion on a strict interpretation of the LGC, which states that LGUs have the authority to pass laws "pursuant to national policies and subject to supervision, control, and review of the DENR", that pertain to the "enforcement of forestry laws limited to community-based forestry projects, pollution control law, small-scale mining act, and other laws on the protection of the environment". The DILG has placed emphasis upon the 
requirement that such laws comply with national policy to encourage more mining in rendering its opinion that such moratoriums are invalid. On the other hand, LGUs based their implementation of mining moratoriums from a broad reading of the LGC as well as by using the provisions of the Wildlife Resources Conservation and Protection Act that empower LGUs with the ability to declare areas within their jurisdictions "wildlife habitat zones", and as such exempt from extractive activities (Holden and Jacobson, 2006).

Finally, non-activation of the "One-Stop-Shop" for mining permits licensing, which was promised by the government, has not been implemented successfully due to varied interpretations of mining regulatory requirements and procedures in the regional offices. This serves as further evidence of regulatory overlap and conflict as a result of decentralisation. This institutional conflict between the central government, and DENR in particular, and LGUs is a legacy of decentralisation in the Philippines, and constitutes significant regulatory risk for foreign mining investors.

\section{Assessment}

Based on the above analysis, it is clear that the performance of the Philippine regulatory regime governing foreign mining investment, against the six main criteria which determine the quality of a regulatory regime, is poor. It is also apparent that the level of informality of the regime is high, as the rules and regulations are unclear, the regulators lack capacity to implement regulations, and the level of regulatory capture is high. In turn, a high degree of informality influences the lack of transparency, accountability, and increases legal and policy uncertainty, and regulatory overlap and conflict, thus reinforcing the poor performance of the regime.

\section{Policy Recommendations}

Given that the benefits, in terms of FDI inflows, of investing in a country's governance infrastructure, are most pronounced for developing countries (Globerman and Shapiro, 2002), the Philippines need to improve their governance infrastructure in general, and the regulatory governance in the mining sector in particular. This would reduce regulatory risks for foreign mining investors, and as a result attract more foreign investment in the Philippine mining industry, which is the government's goal. The quality of governance of the regulatory regime can be improved by implementing a number of short to medium-term and long-term measures and policies, and these are outlined below.

The regulatory regime governing foreign mining investment in the Philippines lacks transparency and accountability, and as a result, lacks probity and does not serve the public interest. Thus, some have suggested that the government revokes the 1995 Mining Act and enacts alternative legislation that "more effectively protects the interests of the affected local communities, indigenous peoples and the environment" (Fact-Finding Mission, 2006). Rather than undertake such a time-consuming and costly 
measure, in the short to medium-term, relevant government agencies should work closely with industry, LGUs and civil society representatives to address and tackle impediments to mining, such as implementation issues at the local government level and community perceptions about potential adverse environmental effects and human rights issues. For instance, the government should initiate and conduct regular mining stakeholder meetings, involving relevant government agencies, mining companies, and civil society, where the most pressing issues would be discussed. It is also essential that the DENR and other regulating agencies disclose relevant mining-related data to the public. While public disclosure of information and dialogue between the various stakeholders may not produce a quick fix to all the problems, ensuring a higher level of communication, transparency and accountability in the mining sector would be the first step towards any improvement in stakeholder relations in the future.

It has been established that the regulatory regime governing foreign mining investment in the Philippines has been captured by sectional interests, evident in the high level of cronyism, corruption and graft. As a result, the regulators are biased towards foreign investors. For instance, many in mineaffected communities believe that on top of the financial incentives (Omnibus Code 1987) introduced to attract foreign mining (and other) investment, the Philippine government has made an implicit commitment not to enforce costly social and environmental minimum standards, justifying the costs to people and the environment by focusing on the longterm gains (Christian Aid, 2004). Thus, some have argued that the Philippine government has allowed its reputation for not strictly enforcing environmental standards or protecting indigenous rights to act as an unstated selling point to potential investors (Christian Aid, 2004). However, the conflict with civil society caused by the government's bias towards, and capture by, foreign investors has not had an intended effect, as it has failed to attract desired level of foreign mining investment. If the NCIP enforces the provisions of the IPRA impartially, some of the conflict described above could be precluded (Gutierrez and Borras, 2004), the risks for foreign mining investors could be reduced, and foreign mining investment increased. If the NCIP remains aligned to the mining industry, civil society opposition will remain a serious impediment to mineral development, and conflict between the civil society and the mining industry will continue into the future.

The Philippine government is well aware of the Philippines' reputation for graft and corruption and has appointed a special commission, the National Anti-Crime Commission, to combat the problem. The country also has the Office of the Ombudsman, an anti-graft body, and a special anti-corruption court. Moreover, the government recently produced a strategic plan, formed Mineral Development Council and sought dialogues with concerned stakeholders such as the church and non-governmental organisations, to soften their opposition to mining projects (OPS, 2008). Regardless of its commitment, the government's efforts to stamp out corruption and graft in regulating agencies, such as the DENR, have so far had only limited success (Bhargava and Bolongaita, 2004, EIU, 2007). Since cronyism, corruption and 
graft are so entrenched in the Filipino society and political system, it is unlikely that we will witness any significant improvement without a major structural change in the country. At the same time, improved communication, and regulatory transparency and accountability, as proposed above, are likely to result in a minor reduction in the levels of corruption, graft and other forms of sectional capture which impede impartial regulation of mining activities by the DENR, the NCIP, and other regulators.

There is a high degree of overlap and conflict in the regulatory regime governing foreign mining investment in the Philippines. Unsurprisingly, some have suggested that the government should overhaul the regulatory regime, and for instance, scrap the DENR, and create new agencies (FactFinding Mission, 2006), and the others argue for less regulation and regulatory agencies (Scott, 2004). While both of these arguments have validity for the Philippines in the long-term, in the short to medium-term, they are unlikely to be implemented effectively and to the satisfaction of all relevant stakeholders, and they would be extremely costly for the already cash-strapped government. Instead, all relevant government agencies at national and local level should form an inter-departmental coordinating committee in order to resolve jurisdictional issues and demarcate clear boundaries over their respective areas of control. This process would likely result in the reduction in policy and legal uncertainty and regulatory overlap and/or conflict and, in particular, would reduce red tape during exploration and mining permit application process.

Many of the rationales for regulating can be described as instances of 'market failure'. Regulation in such cases is justified because the uncontrolled market place will fail to produce behaviour or results in accordance with the public interest (Francis, 1993; Baldwin and Cave, 1999). In the case of the regulatory regime governing foreign mining investment in the Philippines the regulation is not absent, but is ineffective and clearly fails to serve the public interest. Thus, in the long-run, the regulatory regime requires a structural overhaul. As a first step towards the structural change, the government should engage in an independent and detailed audit of the performance of the regulatory regime governing mining investment. This may occur in the form of an institutional mapping exercise (for the basis, see Dragos Aligica, 2006), in a manner which would meet public approval, and would be fully transparent and accountable. The audit would enable the government to gain a detailed understanding of the performance of the current regime and the causes of issues at stake, before any long-term measures (i.e. new regulations, restructuring of the regulators) to remove the structural causes of poor regulatory performance are to be made. Regulatory restructuring will succeed only if a detailed, independent and publicly supported audit of the current regime precedes it. Effective and wellfunctioning regulatory governance in the Philippines' mining sector is possible, but it cannot be achieved overnight. 


\section{Conclusion}

This paper examined and assessed the performance of the regulatory regime governing foreign mining investment in the Philippines. Based on this, it outlined various policy recommendations for the Philippine government, which may improve the governance of the sector and in turn attract more foreign investment. The main argument is that the poor performance of the governance structures in the Philippine mining sector is behind the high level of regulatory risk for foreign mining investment, and the low levels of foreign investment.

The Philippine government wants to attract over $\$ 4$ billion in foreign investment to its mining sector by 2010. However, when there is a high degree of uncertainty and conflict in the political and legal spheres, longterm investor confidence is very difficult to achieve, and major mining companies remain reluctant to pour money into the Philippines. Weak governance infrastructure in the sector endows the Philippine government with little bargaining power vis-a-vis potential foreign investors, who clearly hold the upper hand and dictate their own terms in negotiations with the government. For example, Rio Tinto unilaterally announced its withdrawal from the Philippines in 1999 due to the country's inadequate and complicated legal and fiscal regime, and following a strong civil society campaign against its operations in Zamboanga (Christian Aid, 2004). Other major companies, such as BHP Billiton and Anglo-American, have carried out exploration, but have been wary about committing to new projects. Given that foreign mining investment in the Philippines is currently wrapped in a veil of uncertainty, it comes as no surprise that only the bravest and/or the most desperate companies are willing to embark on the Philippine adventure. Junior companies looking to expand their portfolios constitute the core of foreign mining presence in the Philippines. However, given the Philippines' enormous mining potential, if some of the outlined policies and measures to improve the governance of the sector are considered and implemented by the government, it may not be too long before the majors enter the Philippines. 


\section{References}

Aguilar, J.L., 2008. Data Mining. Newsbreak, Special Issue, July-September.

Aldaba, F.T., 2002. Philippine NGOs and multistakeholder partnerships: Three case studies. Voluntas, 13(2): 179-192.

Baldwin, R., and Cave, M., 1999. Understanding Regulation: Theory, Strategy, and Practice. Oxford University Press, New York.

Balgos, C.C.A. (Ed.), 2001. Investigating Local Governments: A Manual for Reporters. Philippine Center for Investigative Journalism, Manila.

Ballesteros, A.G.G., 2001. Spin miners: The continuing sale of the country's natural resources. Tanawan, 4: 1-7.

Banlaoi, R., 2004. Globalization and Nation-Building in the Philippines: State Predicaments in Managing Society in the Midst of Diversity. In: Sato, Y. (Ed.), Growth and Governance in Asia. Asia-Pacific Center for Security Studies, Hawaii.

Bautista, C., 2007. Arroyo family virtually controls mining industry. Kalikasan-PNE Press Release, 1 August.

Bhargava, V., and Bolongaita, E., 2004. Challenging Corruption in Asia: Case Studies and a Framework for Action. The World Bank, Washington, D.C.

Bridge, G., 2004. Mapping the bonanza: Geographies of mining investment in an era of neoliberal reform. Professional Geographer, 56(3): 406-420.

Brown, A.C., and De Paula, E., 2002. Strengthening of the Institutional and Regulatory Structure of the Brazilian Power Sector. World Bank Report on the PPIAF Project for Brazil Power Sector, Task 4, World Bank.

Bryant, R.L., 2005. Nongovernmental Organizations in Environmental Struggles: Politics and the Making of Moral Capital in the Philippines. Yale University Press, New Haven.

Business World, 2005. RP, Indonesia seen benefiting from substantial mineral reserves. 11 October.

Cariño, L.V., 2002. Regulatory Governance in the Philippines: A Profile. Centre on Regulation and Competition, Working Paper Series, Paper No. 44, December.

Catholic Bishops' Conference of the Philippines (CBCP), 2006. A statement on mining issues and concerns. 29 January. 
Chase, R., and Lugue, F., 2006. The Philippines: Reviving Fortunes. Ambrian Economic Update, 18 October.

Christian Aid, 2004. Breaking promises, making profits: Mining in the Philippines. A Christian Aid and PIPLinks report, December.

Conde, C.H., 2007. Family Ties Bind Philippine Government. The New York Times, 13 May.

Courtney, C. A., White, A. T., and Deguit, E., 2002. Building Philippine local government capacity for coastal resource management. Coastal Management, 30: 27-45.

Cubbin, J., and Stern, J., 2004. Regulatory Effectiveness: The Impact of Good Regulatory Governance on Electricity Industry Capacity and Efficiency in Developing Countries. City University, London, Department of Economics Discussion Paper Series No. 04/04.

Dragos Aligica, P., 2006. Institutional and Stakeholder Mapping: Frameworks for Policy Analysis and Institutional Change. Public Organization Review, 6: 79-90.

Economist Intelligence Unit (EIU), 2007. Philippines Risk. Risk Briefing, 15 October.

Eisner, M.A., 2000. Regulatory Politics in Transition. Johns Hopkins University Press, Baltimore.

Estabillo, A.V., 2005. CBCP NASSA doubts mining benefits. Mindanews, 12 April.

Fact Finding Mission, 2006. Mining in the Philippines: Concerns and Conflicts. Report of a Fact-Finding Trip to the Philippines, July-August.

Francis, J., 1993. The Politics of Regulation. Oxford University Press, New York.

Fraser Institute, 2007. The Fraser Institute Annual Survey of Mining Companies 2006/07.

Freeman, R.E., Harrison, J.S., and Wicks, A.C., 2007. Managing for Stakeholders: Survival, Reputation, and Success. Yale University Press, New Haven and London.

Gaerlan, K.N., 2005. Touching Lives: CIDA's Encounters with Indigenous Peoples in the Philippines. Canadian International Development Agency (CIDA). 
Girouard, M., 1996. The Philippines: human rights and forest management in the 1990s. Human Rights Watch, 8(3), 1-25.

Globerman, S., and Shapiro, D., 2002. Global Foreign Direct Investment Flows: The Role of Governance Infrastructure. World Development, 30(11), 1899-1919.

Globerman, S., and Shapiro, D., 2003. Governance Infrastructure and U.S. Foreign Direct Investment. Journal of International Business Studies, 34(1), 19-39.

Go, M.G.A., 2008. First, Please Clean Up. Newsbreak, Special Edition, JulySeptember.

Gutiérrez, E., and Borras, S.J., 2004. The Moro Conflict: Landlessness and Misdirected State Policies. East-West Center, Washington Policy Studies Series 8: 1-89, 3 September.

Gutiérrez, L.H., 2003. Regulatory Governance in the Latin American Telecommunications Sector. Utilities Policy, 11(4): 225-240.

Holden, W.N., 2005. Civil Society Opposition to Nonferrous Metals Mining in the Philippines. Voluntas: International Journal of Voluntary and Nonprofit Organizations, 16(3): 223-249.

Holden, W.N., and Ingelson, A., 2007. Disconnect between Philippine Mining Investment Policy and Indigenous Peoples' Rights. Journal of Energy \& Natural Resources Law, 25(4): 375-391.

Holden, W.N. and Jacobson, R.D., 2007a. Ecclesial Opposition to Nonferrous Metals Mining in the Philippines: Neoliberalism Encounters Liberation Theology. Asian Studies Review, 31(2): 133-154.

Holden, W.N., and Jacobson, R.D., 2007b. Mining amid armed conflict: nonferrous metals mining in the Philippines. The Canadian Geographer/Le Géographe Canadien, 51(4): 475-500.

Holden, W.N., and Jacobson, R.D., 2006. Mining amid decentralization. Local governments and mining in the Philippines. Natural Resources Forum, 30(3): 188-198.

Hutchcroft, P., 1997. The Politics of Privilege: Assessing the Impact of Rents, Corruption, and Clientelism on Philippine Development. Institute for Popular Democracy Occasional Paper No. 1.

Jamison, M.A., Holt, L., and Berg, S.V., 2005. Measuring and Mitigating Regulatory Risk in Private Infrastructure Investment. The Electricity Journal, 18(6): 36-45. 
Kaufmann, D., Kraay, A., and Mastruzzi, M., 2004. Governance Matters III: Governance Indicators for 1996-2002, World Bank, New York.

Konstantin Galvez, J., 2007. Bloody mining conflict looms---NGO. Manila Times. 17 August.

Kurtzman, J., Yago, G., and Phumiwasana, T., 2004. The Global Costs of Opacity. MIT Sloan Management Review, 46(1): 38-44.

Landingin, R., 2008. Unearthing Strife. Newsbreak, Special Edition, JulySeptember.

Le Billon, P., 2005. Fuelling War: Natural Resources and Armed Conflict. Adelphi Paper 373, The International Institute for Strategic Studies, London.

Legaspi, P.E., 2001. The changing role of local government under a decentralized state: The Case of the Philippines. Public Management Review, 3(1): 131-139.

Linantud, J. L., 2005. The 2004 Philippine elections: political change in an illiberal democracy. Contemporary Southeast Asia, 27(1): 80-101.

Milo, M.S., 2007. Integrated Financial Supervision: An Institutional Perspective for the Philippines. ADB Institute Discussion Paper No. 81, October.

Mines and Geosciences Bureau. The Philippine Minerals Industry Profile, http://www.mgb.gov.ph.

Moran, T.H., 1999. Political and Regulatory Risk in Infrastructure Investment in Developing Countries: Introduction and Overview. The CEPMLP Internet Journal, 5-6.

North, D.C., 1990. Institutions, Institutional Change and Economic Performance, Cambridge University Press, New York.

OECD, 2001. The well-being of nations: the role of human and social capital, OECD, Paris.

Office of the Press Secretary (OPS), 2008. PGMA orders expanded role for LGUs in management of mineral resources. 10 January.

Otto, James, 1992. The Philippines: the effect of an interim regulatory system on foreign mineral investment. In: Otto, J., and Wälde, T. (Eds.), Mineral investment conditions in selected countries of the Asia-Pacific region. United Nations Economic and Social Commission for Asia and the Pacific, New York, 207-38. 
Philippine Supreme Court, 2004. La Bugal - B'laan Tribal Association v. Ramos. 1 December.

Rodell, P.A., 2004. The Philippines: playing out long conflicts. Southeast Asian Affairs, 189-204.

Scott, C., 2004. Regulation in the age of governance: the rise of the postregulatory state. In: Jordana, J., and Levi-Faur, D. (Eds.), The Politics of Regulation: Institutions and Regulatory Reforms in the Age of Governance. Edward Elgar, Cheltenham, UK, 145-174.

Snell, M. B., 2004. The cost of doing business. Sierra Magazine, May/June, 34-79.

Stark, J., 2007. A Double-Edged Sword? Implications of Mining for Environmental Security in the Philippines. Foundation for Environmental Security and Sustainability, April.

Starke, L., 2002. Breaking New Ground: Mining, Minerals, and Sustainable Development. Earthscan, London.

Stavenhagen, R., 2003. Report of the Special Rapporteur on the Situation of Human Rights and Fundamental Freedoms of Indigenous People. United Nations, New York.

Structural Adjustment Participatory Review International Network (SAPRIN), 2001. 'The Impact of Investment Liberalization and the Mining Act of 1995 on Indigenous Peoples, Upland Communities and the Rural Poor, and on the Environment: A summary report. Draft report presented at the Second National Forum on 5-6 April, Manila.

World Resources Institute, 2005. Electricity Governance Toolkit: Benchmarking Best Practices and Promoting Accountability in the Electricity Sector. National Institute of Public Finance and Policy, and Prayas-Prune. 